\title{
OXIDATIVE STRESS IN TRAINING, OVERTRAINING AND DETRAINING: FROM EXPERIMENTAL TO APPLIED RESEARCH
}

\author{
Radica Dragojlovic Ruzicic ${ }^{1}$, Vladimir Jakovljevic ${ }^{1}$, Dusica Djordjevic ${ }^{1}$
}

${ }^{1}$ Department of Physiology, Faculty of Medical Sciences, University of Kragujevac, Serbia

\author{
OKSIDATIVNI STRES U TRENIRANOSTI, PRETRENIRANOSTI I \\ DETRENIRANOSTI: \\ OD EKSPERIMENTALNIIH DO PRIMENJENIH ISTRAŽIVANJA \\ Radica Dragojlović Ružičić ${ }^{1}$, Vladimir Jakovljević ${ }^{1}$, Dušica Đorđević ${ }^{1}$ \\ ${ }^{1}$ Katedra za Fiziologiju, Fakultet Medicinskih nauka, Univerzitet u Kragujevcu, Srbija
}

\section{ABSTRACT}

According to the hormesis theory, the responses of biological systems to stressors in exercise training may be explained by a U-shaped curve with inactivity and overtraining as the two endpoints. Both of these endpoints decrease physiological functions. Markers of oxidative stress may be important parameters for biological monitoring of athletes. Numerous studies have shown that acute exercise has the potential to induce oxidative stress, but regular exposure to an increased level of prooxidants leads to upregulation of the endogenous antioxidative defence system (ADS) of an athlete. Studies that explored the redox state in athletes during the competitive season showed that the antioxidative status changes depending on the training load and training phase. During the training season, a state of fatigue known as overtraining may occur, which results from an excessive training load. Oxidative stress has been suggested as one of the causes of overtraining syndrome. Based on the existing studies, it can be said that a connection exists, but whether oxidative stress is a cause or a consequence of overtraining is yet to be clarified. Furthermore, detraining (training reduction or cessation) leads to a partial or complete loss of training-induced anatomical, physiological and performance adaptations; therefore, it seems reasonable to assume that changes in ADS are also reversible.

Keywords: redox state, athletes, overtraining syndrome, detraining, adaptation

\section{SAŽETAK}

Prema teoriji hormezije, odgovori bioloških sistema na stresore koji deluju tokom treninga mogu da se objasne " $U$ " krivom, čija su dva kraja neaktivnost i pretreniranost. Obe navedene krajnosti imaju za posledicu pogoršanje fizioloških funkcija. Markeri oksidativnog stresa mogu biti važni parametri biološkog praćenja sportista. Veliki broj studija je pokazao da akutno vežbanje ima potencijal da izazove oksidativni stres, ali da redovno izlaganje tela povišenom nivou prooksidanata vodi ushodnoj regulaciji endogenog antioksidativnog sistema sportiste. Studije koje su ispitivale redoks status sportista tokom takmičarske sezone pokazale su da se antioksidativni status menja u zavisnosti od trenažnog opterećenja i trenažne faze. Tokom trenažne sezone, kao posledica preteranog opterećenja, može nastati stanje umora poznato kao pretreniranost. Oksidativni stres je predložen kao jedan od uzroka sindroma pretreniranosti. Na osnovu postojećih studija, može se reći da veza postoji, ali da li je oksidativni stres uzrok ili posledica pretreniranosti tek treba da bude razjašnjeno. $S$ druge strane, detreniranost (smanjenje ili redukcija treninga) izaziva parcijalni ili totalni gubitak anatomskih, fizioloških i takmičarskih adaptacija izazvanih treningom, pa je razumno očekivati da su promene u antioksidativnom sistemu sportiste takođe reverzibilne..

Ključne reči: redoks status, sportisti, sindrom pretreniranosti, detreniranost, adaptacija

\section{INTRODUCTION}

Oxidative stress is a condition in which the delicate balance that exists between the production of prooxidants and their subsequent amelioration via the antioxidant defence system (ADS) becomes skewed in favour of prooxidants (1). Exercise provides an excellent model to study the dynamic balance between oxidative challenges and antioxidant defence in biological systems. From the work pub-

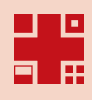

lished during the previous 3 decades, it is now known that acute exercise of sufficient volume, intensity and duration can increase reactive oxygen and nitrogen species (RONS) production, which can lead to the oxidation of several biological molecules (1-4). However, repeated exposure of the system to increased RONS production from chronic exercise training leads to an upregulation in the endogenous 
ADS (1-4). This provides adaptive protection from RONS during subsequent training sessions, as well as during nonexercise related conditions.

According to the hormesis theory, the response of a biological system to stressors during exercise training can be explained by a U-shaped curve for which the two endpoints are inactivity and overtraining (5). Both of these endpoints result in decreased physiological functions (3). Markers of oxidative stress may be important parameters of biological monitoring of athletes (6). Studies that have explored the redox state in athletes during the competitive season have shown that the antioxidative status changes depending on the training load and training phase (7-13). Periods of intensive training may lead to a decrease in antioxidative capacity and a consequent increase in oxidative stress. Although there is no clear evidence yet, oxidative stress has been suggested as one of the underlying mechanisms of overtraining syndrome (14). However, detraining (training reduction or cessation) leads to a partial or complete loss of training-induced anatomical, physiological and performance adaptations $(15,16)$. Thus, it seems reasonable to assume that changes in the ADS are also reversible.

\section{OXIDATIVE STRESS IN TRAINING}

The relationship between physical activity and oxidative stress has gained the attention of scientists, and as a result, hundreds of papers have been published on this topic. In those studies, oxidative stress was estimated using various methods and parameters (direct detection of free radicals; measuring radical-mediated damage of lipids, proteins and DNA; and measuring the activity of antioxidative enzymes or the concentrations of nonenzymatic antioxidants). Some studies have been conducted under laboratory conditions, e.g., athletes subjected to (sub)maximal exercise protocols on a treadmill, cycling ergometer or some other ergometer, whereas others followed changes in the redox state of athletes following sport-specific physical activity (training or competition). The majority of investigators have explored oxidative stress induced by aerobic exercise (running, swimming, cycling, triathlon, etc.), but there is a somewhat smaller number of studies on the relationship between anaerobic exercise and oxidative stress (sprinting, jumping, training with resistance, etc.). A few of these papers examined oxidative stress in team sports characterised by a combination of aerobic and anaerobic capabilities (basketball, handball, football, etc.).

When exploring the relationship between oxidative stress and exercise, one must distinguish between the effect of an acute exercise session and a regular training process. A detailed review of the existing literature on the relationship between acute and/or chronic exercise and oxidative stress is beyond the scope of this paper, and readers are referred to some excellent review papers, such as those by Ji (17), Bloomer and Goldfarb (18), Finaud and colleagues (2), Fisher-Wellman and Bloomer (1), and Lewis et al. (6).
Generally, the data on the acute effects of exercise on redox homeostasis in humans are equivocal because many types of exercise and experimental conditions were used in previous studies. Some studies showed an increase in the levels of lipid peroxidation after (sub)maximal exercise, whereas some did not report this. As a consequence of increased free radical production, the activity of antioxidative enzymes also changed in the majority of studies. However, the results of some studies are conflicting in regard to the direction and extent of change in the activity of different enzymes. Some studies reported increased activity of superoxide dismutase, catalase and glutathione peroxidase, whereas others reported their activity decreased or showed no significant change after acute exercise. The levels of nonenzymatic antioxidants in plasma, urine or tissues also changed with exercise. Many studies measured the levels of reduced glutathione and found that they were decreased after aerobic exercise, whereas the levels of the oxidised form of glutathione were increased. Because of these inconsistencies in the literature, we can only conclude that both acute aerobic and anaerobic exercises have the potential to increase free radical production, which may or may not result in acute oxidative stress (1). The extent of oxidative stress induced by an acute bout of exercise depends on many factors, such as the exercise mode, intensity and duration; the participant's state of training; gender; age; nutrition habits, etc. For example, our research team showed that sport-specific and sport-nonspecific bouts of exercise induce different redox responses in athletes (19). It seems that unaccustomed, short, and intensive physical activity may induce oxidative stress in trained athletes, whereas sport-specific activity of longer durations with a proper warm-up period may not (19). Interestingly, basal levels of antioxidants may also affect an individual's response to exercise-we have shown that, in a group of young handball players, the levels of hydrogen peroxide, nitric oxide, superoxide dismutase and catalase were changed after exercise only in athletes with the lowest basal superoxide dismutase activity (20). Different basal (rest) levels of antioxidants are certainly a consequence of the training process, and consequently, the fitness level of an individual. Different types of sports affect the basal and acute redox states differently (21). Although exercise-induced increase in RONS production has the potential to result in significant cell disturbances, in accordance with the theory of hormesis, a low grade oxidative stress appears necessary for various physiological adaptations to take place (3). There is increasing evidence that low-to-moderate levels of cellular prooxidants play an important role in the modulation of muscle force, control of cell signalling pathways and regulation of gene expression (22-25). Regular exposure to an increased level of prooxidants leads to upregulation of the endogenous antioxidative system, which shifts the redox state of an athlete towards a more reducing environment that is suitable for cells $(1,3)$. However, to induce adaptive changes, i.e., improve the efficacy of the antioxidative defence, a training programme must be long enough and have adequate intensity. A well-planned and controlled aerobic exercise training 
programme was shown to induce an increase in antioxidative enzyme activity in plasma and other tissues (especially in initially unfit subjects), although this adaptation was not always correlated with an increase in the maximal oxygen consumption. However, this does not mean there is no relationship between cardiorespiratory fitness and the redox state of an individual (26). Many studies have compared the antioxidant status of trained and untrained subjects at rest and revealed a higher antioxidant capacity in the blood and muscles of athletes. This basal difference certainly affects the response of the redox system to acute exercise. Well-trained subjects experience less oxidative stress than untrained subjects when exposed to exercise (27).

\section{OXIDATIVE STRESS IN OVERTRAINING}

During the training season, a state of fatigue resulting from an excessive training load known as overtraining can occur. To induce structural and functional adaptations that enable improvements in sport performance, athletes and coaches manipulate the training load through adjustments in intensity, duration and frequency, or through a reduction of the regenerative period (28). Every athletic training program includes a component of repetitive overloading, but with an inadequate recovery time or an abrupt increase in training load, overloading may produce undesired effects, such as chronic fatigue or a lack of performance improvements, i.e., overtraining (29).

Although there is no direct evidence yet, oxidative stress has been suggested as one of the causes of overtraining syndrome (30-33). Cellular damage, especially on the muscular level, is associated with the inflammatory processes that occur during the repair of damaged tissue, and this inflammation can lead to further production of prooxidants by neutrophils and macrophages (34). On the other hand, nitric oxide and reactive oxygen species play a key role in the regulation of immune functions, affecting virtually every step in the development of inflammation (35). For example, low concentrations of nitric oxide inhibit cytokine expression, whereas high levels of nitric oxide can be toxic and proinflammatory (35). Thus, monitoring the markers of oxidative stress during the season can be useful for timely detection of athletes who are at increased risk for overtraining, and steps can be taken to avoid adverse consequences, especially in regard to the health and sport performance of athletes (12).

The number of studies that have examined the relationship between oxidative stress and overtraining is very small. Human studies have shown that overtrained athletes have higher levels of oxidative stress markers at rest compared to controls, and these levels increase with exercise $(30,33)$. Generally, investigation of the mechanisms behind overtraining syndrome in humans is difficult because performing longitudinal studies in which athletes are trained in such a manner that they develop overtraining syndrome is unethical. Thus, animal overtraining models have been developed (36, 37). Animal (rat) models often allow for more invasive, extensive, and homogenous experimental designs than those used with human subjects. Using rat experimental models enables the manipulation of individual and external variables that are commonly investigated in human studies and allows invasive analyses; therefore, they can precisely characterise the adaptations that occur.

Ferraresso and colleagues (38) recently published the results of a study conducted on rats that were subjected to an 11-week training protocol designed to cause overtraining. Compared to rats in the control group and rats that did not develop overtraining, overtrained rats had significantly increased values of lipid peroxidation, as well as increased activity of superoxide dismutase, catalase and glutathione reductase in both muscle and blood (38). The authors concluded that the increased level of antioxidant protection represents an adaptive mechanism that protected the overtrained rats from increased ROS production. Using the same protocol for inducing overtraining, Dong and colleagues (39) investigated oxidative damage in the neutrophils of rats. They concluded that overtraining can activate NADPH oxidase-mediated overproduction of RONS (which they quantified through levels of malondialdehyde in the blood) and that NADPH oxidase was responsible for apoptosis of neutrophils and lymphocyte DNA damage in overtrained rats. Ogonovszky and colleagues investigated the effects of moderate, high and excessive training loads on the markers of oxidative stress and DNA damage in the brain (40) and liver (41) of rats. They found that overtraining did not induce oxidative stress in the brain (40), but it led to oxidative damage to nuclear DNA in the liver (41). Zoppi and Macedo (42) found that oxidative stress was dependent on fibre type in different muscles of overtrained rats. Pereira and colleagues (43) showed that overtraining induced in Swiss mice through training sessions of downhill running was associated with oxidative stress in skeletal muscle cells and total blood. Our research team recently conducted a study that aimed to induce overtraining in rats through an experimental swimming protocol and explored the redox state of rats at both systemic (in blood) and local levels (in the coronary effluent of an isolated rat heart, unpublished data). Although the differences in the levels of pro/antioxidants in the blood of moderately trained rats and rats trained according to an experimental overtraining protocol were not statistically significant. The overtrained rats had the highest levels of the three measured endogenous antioxidants, which was probably an adaptation that occurred to cope with increased oxidative demands of multiple daily training sessions (44). Furthermore, compared to controls, the hearts of those rats produced lower levels of superoxide anion radicals and hydrogen peroxide.

\section{OXIDATIVE STRESS IN DETRAINING}

According to the principle of reversibility, traininginduced physiological adaptations are transitory and may disappear when the training load is not sufficient. This can 
result from training reductions (a progressive or nonprogressive reduction of the training load during a variable period of time to reduce the physiological and psychological stress of daily training), training cessation (a temporary discontinuation or complete abandonment of a systematic programme of physical conditioning), or confinement to bed rest due to illness or injury (15). The characteristics of detraining may differ depending on the duration of training cessation or insufficient training $(15,16)$.

The number of studies on the reversibility of adaptations in the antioxidative system in athletes is even smaller than the number of studies on the effects of overtraining. Fatouros and coauthors (45) explored oxidative stress in older men during training (16 weeks, walking/running 3 times a week) and detraining (after 4 months) and showed that endurance training lowered lipid peroxidation and increased glutathione peroxidase activity and total antioxidant capacity, but detraining abolished these adaptations. The reversibility of positive training-induced changes in the redox state of exercisers was also confirmed in a study by Radak and colleagues (46) who explored oxidative stress in the brains of rats subjected to training and detraining. Agarwal and coauthors (47) showed that regular exercise improves superoxide dismutase levels in the paraventricular nucleus of rats, but two weeks of detraining caused a reversal of exercise-induced improvement in antioxidant status within the paraventricular nucleus of hypertensive rats. In contrast, exercise or detraining did not affect superoxide dismutase levels in normotensive rats (47). Finally, Rodrigues and coauthors (48) evaluated the effects of exercise training and detraining on inflammatory and metabolic profiles after myocardial infarction in rats. They observed no expressive changes in oxidative stress in adipose tissue in the experimental groups (control, sedentary infarcted, trained infarcted, detrained infarcted) (48). Our research team recently designed a project aiming to elucidate sex differences in cardiac adaptations to training and detraining in rats, as well as the extent, mechanisms and speed of changes of selected cardiodynamic, morphological parameters and oxidative stress parameters in the heart and blood of rats. However, those experiments are still in progress.

\section{CONCLUSION}

Although the results of hundreds of studies on the relationship between oxidative stress and exercise training are equivocal because of the many types of exercises and experimental conditions used in those studies, it is generally accepted that regular exercise improves the redox state of exercisers. Because of a small number of studies, the importance of oxidative stress in the development of overtraining is still unclear. Based on the existing studies, it can be said that a connection exists, but whether oxidative stress is a cause or consequence of overtraining is yet to be clarified. Detraining abolishes adaptations in the
ADS of exercisers; however, the precise characteristics of such changes in the ADS due to detraining also cannot be clearly defined by exploring the existing literature.

\section{Acknowledgements:}

This work was supported by Grant No. 175043 from the Ministry of Science and Technical Development of the Republic of Serbia and a Junior Project 08/14 by the Faculty of Medical Sciences, Kragujevac, Serbia.

\section{Conflict of interests:}

None declared.

\section{REFERENCES}

1. Fisher-Wellman K, Bloomer RJ. Acute exercise and oxidative stress: a 30 year history. Dyn Med 2009; 8:1-25.

2. Finaud J, Lac G, Filaire E. Oxidative stress: relationship with exercise and training. Sports Med 2006; 36(4):327-58.

3. Radak Z, Chung HY, Koltai E, Taylor AW, Goto S. Exercise, oxidative stress and hormesis. Ageing Res Rev 2008; 7(1):34-42.

4. Vollaard NB, Shearman JP, Cooper CE. Exercise-induced oxidative stress: myths, realities and physiological relevance. Sports Med 2005; 35(12):1045-62.

5. Stojanovic Tosic J, Jakovljevic V, Zivkovic V, Srejovic I, Valdevit Z, Radovanovic D, et al. Biphasic response of cardiodynamic adaptations to swimming exercise in rats. Gen Physiol Biophys 2015; 34(3):301-10.

6. Lewis NA, Howatson G, Morton K, Hill J, Pedlar CR. Alterations in redox homeostasis in the elite endurance athlete. Sports Med 2015; 45(3):379-409.

7. Concepcion-Huertas M, Chirosa LJ, De Haro T, Chirosa IJ, Romero V, Aguilar-Martinez D, et al. Changes in the redox status and inflammatory response in handball players during one-year of competition and training. J Sports Sci 2013; 31(11):1197-207.

8. Finaud J, Scislowski V, Lac G, Durand D, Vidalin H, Robert A, et al. Antioxidant status and oxidative stress in professional rugby players: evolution throughout a season. Int J Sports Med 2006; 27(2):87-93.

9. Marin DP, Bolin AP, Campoio TR, Guerra BA, Otton R. Oxidative stress and antioxidant status response of handball athletes: Implications for sport training monitoring. Int Immunopharmacol 2013; 17(2):462-70.

10. Schippinger G, Fankhauser F, Abuja PM, WinklhoferRoob BM, Nadlinger K, Halwachs-Baumann G, et al. Competitive and seasonal oxidative stress in elite alpine ski racers. Scand J Med Sci Sports 2009; 19(2):206-12.

11. Schippinger G, Wonisch W, Abuja PM, Fankhauser F, Winklhofer-Roob BM, Halwachs G. Lipid peroxidation and antioxidant status in professional American football players during competition. Eur J Clin Invest 2002; 32(9):686-92. 
12. Teixeira V, Valente H, Casal S, Pereira L, Marques F, Moreira P. Antioxidant status, oxidative stress, and damage in elite kayakers after 1 year of training and competition in 2 seasons. Appl Physiol Nutr Metab 2009; 34:716-24.

13. Varamenti EI, Kyparos A, Veskoukis AS, Bakou M, Kalaboka S, Jamurtas AZ, et al. Oxidative stress, inflammation and angiogenesis markers in elite female water polo athletes throughout a season. Food Chem Toxicol 2012; 61:3-8.

14. Kreher JB, Schwartz JB. Overtraining syndrome: a practical guide. Sports Health 2012; 4(2):128-38.

15. Mujika I, Padilla S. Detraining: loss of training-induced physiological and performance adaptations. Part I: short term insufficient training stimulus. Sports Med 2000; 30(2):79-87.

16. Mujika I, Padilla S. Detraining: loss of training-induced physiological and performance adaptations. Part II: Long term insufficient training stimulus. Sports Med 2000; 30(3):145-54.

17. Ji LL. Antioxidants and oxidative stress in exercise. Exp Biol Med 1999; 222(3):283-92.

18. Bloomer RJ, Goldfarb AH. Anaerobic exercise and oxidative stress: a review. Can J Appl Physiol 2004; 29(3):245-63.

19. Djordjevic D, Cubrilo G, Puzovic V, Vuletic M, Zivkovic V, Barudzic N, et al. Changes in athlete's redox state induced by habitual and unaccustomed exercise. Oxid Med Cell Long 2012; 2012:805850.

20. Djordjevic D, Cubrilo D, Zivkovic V, Barudzic, N, Vuletic M, Jakovljevic V. Pre-exercise superoxide dismutase activity affects the pro/antioxidant response to acute exercise. Ser J Exp Clin Res 2010; 11(4):145-53.

21. Cubrilo D, Djordjevic D, Zivkovic V, Djuric D, Blagojevic D, Spasic M, et al. Oxidative stress and nitrite dynamics under maximal load in elite athletes: relation to sport type. Mol Cell Biochem 2011; 355(1-2):273-9.

22. Dröge W. Free radicals in the physiological control of cell function. Physiol Rev 2002; 82(1):47-95.

23. Powers SK, Duarte J, Kavazis AN, Talbert EE. Reactive oxygen species are signaling molecules for skeletal muscle adaptation. Exp Physiol 2010; 95(1):1-9.

24. Powers SK, Nelson WB, Hudson MB. Exercise-induced oxidative stress in humans: cause and consequences. Free Radic Biol Med 2011; 51(5):942-50.

25. Radak Z, Zhao Z, Koltai E, Ohno H, Atalay M. Oxygen consumption and usage during physical exercise: the balance between oxidative stress and ROS-dependent adaptive signaling. Antioxid Redox Signal 2013; 18(10):1208-46.

26. Djordjevic D, Cubrilo D, Macura M, Barudzic N, Djuric $\mathrm{D}$, Jakovljevic V. The influence of training status on oxidative stress in young male handball players. Mol Cell Biochem 2011; 351(1-2):251-9.

27. Djordjevic D, Cubrilo D, Barudzic N, Vuletic M, Zivkovic V, Nesic M, et al. Comparison of blood pro/antioxidant levels before and after acute exercise in athletes and nonathletes. Gen Physiol Biophys 2012; 31(2):211-9.
28. Issurin VB. New horizons for the methodology and physiology of training periodization. Sport Med 2010; 40(3):189-206.

29. Meeusen R, Duclos M, Foster C, Fry A, Gleeson M, Nieman D, et al. Prevention, diagnosis, and treatment of the overtraining syndrome: joint consensus statement of the European College of Sport Science and the American College of Sports Medicine. Med Sci Sports Exerc 2013; 45(1):186-205.

30. Margonis K, Fatouros IG, Jamurtas AZ, Nikolaidis MG, Douroudos I, Chatzinikolaou A, et al. Oxidative stress biomarkers responses to physical overtraining: implications for diagnosis. Free Radic Biol Med 2007; 43(6):901-10.

31. McKenzie DC. Markers of excessive exercise. Can J Appl Physiol 1999; 24(1):66-73.

32. Petibois C, Cazorla G, Poortmans JR, Déléris G. Biochemical aspects of overtraining in endurance sports. Sports Med 2002; 32(13):867-78.

33. Tanskanen M, Atalay M, Uusitalo A. Altered oxidative stress in overtrained athletes. J Sports Sci 2010; 28(3):309-17.

34. Tiidus PM. Radical species in inflammation and overtraining. Can J Physiol Pharmacol, 1998; 76(5): 533-8.

35. Guzik TJ, Korbut R, Adamek-Guzik T. Nitric oxide and superoxide in inflammation and immune regulation. J Physiol Pharmacol 2003; 54(4):469-87.

36. Hohl R, Ferraresso RL, De Oliveira RB, Lucco R, Brenzikofer R, De Macedo DV. Development and characterization of an overtraining animal model. Med Sci Sports Exerc 2009; 41(5):1155-63.

37. Pereira BC, Filho LA, Alves GF, Pauli JR, Ropelle ER, Souza CT, et al. A new overtraining protocol for mice based on downhill running sessions. Clin Exp Pharmacol Physiol 2012; 39(9):793-8.

38. Ferraresso RL, de Oliveira R, Macedo DV. Interaction between overtraining and the interindividual variability may (not) trigger muscle oxidative stress and cardiomyocyte apoptosis in rats. Oxid Med Cell Longev 2012; 2012:935483.

39. Dong J, Chen P, Wang R, Yu D, Zhang Y, Xiao W. NADPH oxidase: a target for the modulation of the excessive oxidase damage induced by overtraining in rat neutrophils. Int J Biol Sci 2011; 7(6): 881-91.

40. Ogonovszky H, Berkes I, Kumagai S, Kaneko T, Tahara S, Goto S, et al. The effects of moderate-, strenuousand over-training on oxidative stress markers, DNA repair, and memory, in rat brain. Neurochem Int 2005; 46(8): 635-40.

41. Ogonovszky H, Sasvári M, Dosek A, Berkes I, Kaneko T, Tahara S, et al. The effects of moderate, strenuous, and overtraining on oxidative stress markers and DNA repair in rat liver. Can J Appl Physiol 2005; 30(2):186-95.

42. Zoppi CC, Macedo DV. Overreaching-induced oxidative stress, enhanced HSP72 expression, antioxidant and oxidative enzymes downregulation. Scand J Med Sci Sports 2008; 18(1):67-76. 
43. Pereira BC, Pauli JR, Antunes LM, de Freitas EC, de Almeida MR, de Paula Venâncio V, et al. Overtraining is associated with DNA damage in blood and skeletal muscle cells of Swiss mice. BMC Physiol 2013; 13:11.

44. Stanojevic D, Jakovljevic V, Barudzic N, Zivkovic V, Srejovic I, Parezanovic Ilic K, et al. Overfrequent training does not induce oxidative stress and inflammation in blood and heart of rats. Phys Res 2016; 65(2): in press. IN PRESS.

45. Fatouros IG, Jamurtas AZ, Villiotou V, Pouliopoulou $\mathrm{S}$, Fotinakis $\mathrm{P}$, Taxildaris $\mathrm{K}$, et al. Oxidative stress responses in older men during endurance training and detraining. Med Sci Sports Exerc 2004; 36(12):2065-72.
46. Radak Z, Toldy A, Szabo Z, Siamilis S, Nyakas C, Silye $G$, et al. The effects of training and detraining on memory, neurotrophins and oxidative stress markers in rat brain. Neurochem Int 2006; 49(4):3873-92.

47. Agarwal D, Dange RB, Vila J, Otamendi AJ, Francis J. Detraining differentially preserved beneficial effects of exercise on hypertension: effects on blood pressure, cardiac function, brain inflammatory cytokines and oxidative stress. PLoS One 2012; 7(12):e52569.

48. Rodrigues B, Santana AA, Santamarina AB, Oyama LM, Caperuto ÉC, de Souza CT, et al. Role of training and detraining on inflammatory and metabolic profile in infarcted rats: influences of cardiovascular autonomic nervous system. Mediators Inflamm 2014; 2014:207131. 